\title{
The Local Fairy Tales for Teaching Writing
}

\author{
Wahyu Taufiq ${ }^{1}$ \\ ${ }^{1}$ Universitas Muhammadiyah Sidoarjo, Jl. Mojopahit 666B Sidoarjo, Indonesia \\ email:taufiq@umsida.ac.id
}

\begin{abstract}
The study investigated the use of local fairy tales in teaching writing, particularly in narrative text during pandemic covid19 in TEFL Context. This research used a pre-experimental design using a class of ten grade students of a high school in East Java Indonesia. The results show that the pre-test is 50.33 and post-test is 74.66 which means that there is an improvement after the students got treatment. The N-Gain score is 0.468 and it includes "average criteria". It indicates that by using the local fairy tales in the form of short videos as media can improve students' writing skill of narrative text.
\end{abstract}

Keywords: Fairy tales, Media, Writing Skill, Narrative Text, COVID19.

\section{INTRODUCTION}

Language is the way of people to interact with others. In Indonesia, English language is the international language. Learning English can make people to talk with other people in entire aspect such as business, politics and also education. Thus, government gives English subject in almost any level of formal educations.

There are four basic skills in English. These are speaking, writing, listening, and reading. Four skills must be understood by the student. They have to learn all of the skills to master English language. Writing is a way to produce language and express idea, feeling and opinion [1]. Writing is a part of four basic skills in English besides listening, reading, and speaking that must be taught by the teacher to student. Teacher must explain maximally about writing in the class.

In reality, writing is not only skill, but it also is one of media in communication because users use some media to write down. Writing is a primary means of recording speech, even though it must be acknowledged as a secondary medium of communication, that can help users to have a good socialization, can express idea, feeling, and opinion so that users can have a good interaction with the society [2].

There are many kind of text in writing, such as recount, report, narrative, procedure, descriptive etc. In this research, the researcher uses narrative text as the material. Narrative is a story or tale to tell that consist of chronologically events in speech of writing [3]. The purpose of narrative text is to entertain, amuse the reader about the story. Narrative consist of problematic events that turn into crisis and problem solving to find a resolution. There are three generic structure of narrative text [4]. They are orientation, complication and resolution. Orientation is the beginning of paragraph in which the scene, the setting, and the character introduced in the story. Complication is the middle of narrative where the problem appears. Resolution is where the problem has solved. The problem can be resolved for better or worse.

According to [5] state that there are four form of narrative text, they are Legend, Fable, Fairy tale and science fiction. A legend is a narrative story of human action that told by teller to listener based on the history. Fable is an allegorical story of narrative that has moral point, this story is about animal that speaks like human beings. A fairy tale has unique character such as goblins, dwarves, elves, giant, trolls, fairies, or gnomes and usually using magic or enchantments. Science fiction is a fiction story based on imaginary of creator. Science fiction is a story of narrative treating situation that never can be found in real world.

Based on the preliminary research, many students think that English is a difficult lesson since the materials they got are less suitable with their passion or less attractive. The Pandemic 19 makes the challenge become more complicated. Students have to study at home and some of them really have to relay on theirown to master the material 
To fix this problem, the researcher uses the interesting method to make the class more effective. Using method in learning process has goals to give the students the opportunity to express their own idea [6]. The researcher gives the students Fairy tale film in teaching narrative text in writing skill. The researcher uses fairy tale film because fairy tale is appropriate with narrative.

Students need a good situation when they learn lesson to create their enthusiasm in writing class [7]. By using the fairy tale film, the researcher wants to make the students easier to understand the generic structure of narrative text and also create new condition to make the class quieter and interesting.

\section{RESEARCH METHODOLOGY}

This research uses quantitative method to measure the data. Quantitative research is method that uses scientific principles. The quantitative research is used to investigate the population and sample and for the technique of collecting the data uses research instrument. In this research, the researcher uses preexperimental with "pre-test and post-test in one group design". This method is easier to understand because the result more accurate to compare the condition before treatment. The researcher gave pre-test in the class before the students got the treatment then the researcher gave post-test after the student got the treatment.

Population is all of participant in research subject [8]. Population is the object to do this research. The researcher uses ten grades students of a high school in East Java Provicnce of Indonesia. Purposive sampling is a determining technique that with the certain opinion [9]. For technique sample, the researcher uses purposive sampling to do this research. The teacher gives recommendation to the researcher to do the research in one class which consists of 30 students.

Before doing the research, the researcher has to find the instrument. Validity is important to make whether the instrument is appropriate or not. The researcher uses construct validity to make the instrument is valid. Construct validity uses judgement opinion to measure whether the instrument can be used or not [9]. The researcher consulted the instrument to the judgment experts. The written test is an essay. It is usesd to know the students writing skill. To measure the construct validity, the researcher should give suitable test based on the book and consult it to the expert [9]. The test is based on syllabus and lesson plan. The instrument tools are validated by two validators, they are an English teacher at the school and an English lecturer in Universitas Muhammadiyah Sidoarjo. The technique method of validation is using a rating scale. The rating scale is used to choose the answer with the item number which is served by the researcher, so that the rating scale is more flexible [9]. Here is the guidance of the rating scale:

1) The rating scale criteria are as follow:

Score 5 = Excellent

Score $4=$ Good

Score 3 = Enough

Score $2=$ Less

Score 1 = Bad

2) Number of ideal score (maximum score)

$\Sigma$ Ideal score $=5 \times 5$ respondent $\mathrm{x} \Sigma$ item questionnaire

3) Percentage of scores on data collection results

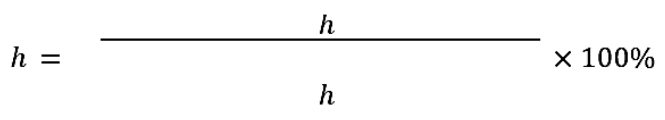

After doing validation in instrument tools, the researcher calculated the data from two validators. The researcher got two scores from correctors and found the mean of the score. From the result, the researcher found that the score of lesson plan is $86.6 \%$ and it includes in excellent criteria. Also, the score of students' worksheet is $90 \%$ and it includes in excellent criteria.

The researcher uses analytical scoring method to know the score of each pre-test and post-test. The researcher cooperates with an English teacher in order to make the score is can be reliable. The analytical scoring used a scoring rubric [10].

The researcher calculated pre-test and post-test that had been collected in the research. The objectives are to know the improvement between pre-test and post-test and also to know the criteria of improvement. The researcher compared the data after giving treatment to the students. To calculate the data from the test, the first, the researcher finds the mean of pre-test and post-test, then the researcher calculates the data using N-Gain formula. Below is the formula of N-Gain [11]:

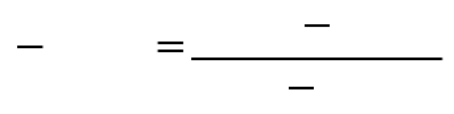

After calculate the $\mathrm{N}$-gain score, then the researcher finds the criteria of N-Gain. To see the criteria, score of $\mathrm{N}-$ Gain it can be categorized as follows [11]: 


\begin{tabular}{|c|c|}
\hline Presentase & Classification \\
\hline $0,00<\mathrm{g}<0,30$ & Low \\
\hline $0,30<\mathrm{g}<0,70$ & Average \\
\hline $0,70<\mathrm{g}<1,00$ & High \\
\hline
\end{tabular}

\section{FINDING AND DISCUSSION}

The reserarch was conducted trough online using various platforms for 3 months, starting from June 2020. The researcher did the research in three meetings. The first meeting, the researcher gave pre-test to them. It is used to know the students' writing skill. In the next meeting, the researcher gave treatment by using fairy tale film to the students. In the last meeting, the researcher gave post-test to know the score after being taught by using fairy tale film.

After got the data score, the researcher started to measure the students score. The first step, to know that there was an improvement or not is to calculate the mean of pre-test and post-test. The mean score of pretest is 52.83 and post-test is 74.66. From the score above, there is an improvement score after the students got treatment. After the mean score of students' pre-test and post-test had been found, the researcher calculated the N-Gain score of the students. The score of N-Gain is 0.468. it means that the N-Gain criteria is "average". The last step is finding the criteria of students' improvement using $\mathrm{N}$-gain criteria. The researcher classified the N-Gain criteria of the students one by one. The N-Gain criteria of students' improvement, there are 4 students get high criteria, 15 students get average criteria, and 11 students get low criteria.

The findings of this study is related to the previous study that had been done by [12] in using fairy tale as the media in teaching narrative text. The result was that there was improvement of students score by using fairy tale story as the media during their studying-at-home activity, because of the pandemic covid19. In addition, this research has improvement score because by using fairy tale film as the media in teaching it can make the materials delivered in the class easier to do.

\section{CONCLUSION}

After the researcher had done the research, it can be concluded that using fairy tale film as media in teaching narrative text can improve students' writing skill particularly during pandemic covid19, that asked students to study from home. It can be known of pre-test and post-test score. The score is increased after the students got treatment. The score can improve because the class is more quiet and interesting. The students paid attention to the film from starting until finishing. Most of the students agreed that using fairy tale film could help them in learning writing. The most important factor to affecting the students in writing class is the student's attention. After got the attention, they would interest with the lesson. So, fairytale film has important effect to make them focus and enthusiast with the lesson.

\section{ACKNOWLEDGMENT}

It would not have been possible to write this research without the help from the kind people around the researcher during the process of the research. The researcher owes deepest appreciation and gratitude to the teacher and lecturers involved on this project, as well as some students who supported and assisted as well as the students as the participant.

\section{REFERENCES}

[1] Hermer, Jeremy. 2001. The Practice of English Language Teaching $3^{\text {rd }}$ Ed. Longman: Pearson Education.

[2] Byrne, Donn. 1980. Teaching Writing Skill. London; Longman Group Ltd (Hornsby, 1974: 561)

[3] Wardiman, Artono. 2008. English Focus 2; For Grade VIII Junior High School (SMP/MTs). Jakarta: Pusat Perbukuan, Departemen Pendidikan Nasional.

[4] Purnamawati, Nuning. 2011. Understanding Texts Type 1. Semarang.

[5] Kreidler, Carol, J. 1965.Visual Aid for Teaching English to the Speakers of Other Languages. Washington D.C. Center For Applied Linguistics.

[6] Harmer, Jeremy. 2001. The Practice of English Language Teaching $3^{\text {rd }}$ Ed. Longman: Pearson Education.

[7] Arikunto, Suharsimi. 2010. Prosedur Penelitian; Suatu Pendekatan Praktek. Jakarta; PT.Rineka Cipta.

[8] Sugiyono . 2017. Metode Penelitian Pendidikan; Pendekatan Kuantitatif, Kualitatif, dan R\&D. Bandung: Alfabeta 
[9] Brown, H, Dougles. 2004. Teaching by Principles: An Interactive Approach to Language Pedagogy. San Fransisco: Longman.

[10] Herlanti, Yanti. 2014. Tanya Jawab Seputar Penelitian Pendidikan Sain. Jakarta: Universitas Syarif Hidayatullah.
[11] Apriana, R, W. 2017. The Effectiveness of Teaching Writing Narrative Text Through Fairytale In SMAN 1 Plos 